\title{
PPBP Gene
}

National Cancer Institute

\section{Source}

National Cancer Institute. PPBP Gene. NCI Thesaurus. Code C26611.

This gene plays a variety of roles in cellular processes such as extracellular matrix synthesis, glucose metabolism, and megakaryocyte differentiation. 